\title{
Sistem Pengelolaan Kegiatan Perusahaan Menggunakan Identifikasi QR Code
}

\author{
Dani Yusuf ${ }^{1, *}$, Joni Warta ${ }^{1,}$ Sri Rejeki ${ }^{1}$ \\ ${ }^{1}$ Fakultas Ilmu Komputer, Universitas Bhayangkara Jakarta Raya, Jl.Perjuangan No.81, \\ Marga Mulya, Kec.Bekasi Utara, Kota Bekasi, Jawa Barat 17143, \\ dani.yusuf@dsn.ubharajaya.ac.id,joniwarta@dsn.ubharajaya.ac.id, \\ sri.rejeki@dsn.ubharajaya.ac.id \\ * Korespondensi: e-mail: dani.yusuf@dsn.ubharajaya.ac.id
}

Diterima: 6 Juli 2021; Review: 6 Juli 2021; Disetujui: 7 Juli 2021; Diterbitkan: 8 Juli 2021

\begin{abstract}
Activities in a company or institution are something that is usually done, the forms of these activities are generally training, socialization of new regulations, inauguration, and so on. These activities need to be recorded and the data managed as documentation or reference and consideration in subsequent activities. This activity requires planning starting from preparation, scheduling, distributing invitations via email, to implementing and recording the attendance of invited participants. The case study was conducted at PT Pelni Indonesia as an Indonesian National Shipping company that often carries out internal activities within the company. The problem that occurs in the management of company activities at PT Pelni is that so far it is still using the manual system. The participant registration process, participant data collection, sending invitations, recording participant attendance and so on are carried out in handwriting and stored in an excel file. Of course, this makes it difficult to search and manage data, and allows data loss or document slippage to occur. One solution that can be used to overcome these problems is to build an information system for managing company activity data. The management system can assist the HRD for data management needed in the implementation of activities carried out by the company. QR Code technology is also used to encrypt participant invitation numbers, verify participant data and to record attendance. The result of developing this system is a data management system for company activities by utilizing Quick Response Code (QR Code) technology. The generated QR Code can store various participant data in only 1 code and is used to verify participant data.
\end{abstract}

Keywords : Invitations to activities; Validate qr code; Quick response code

\begin{abstract}
Abstrak
Kegiatan dalam suatu perusahaan atau institusi merupakan sesuatu hal yang biasa dilakukan, bentuk-bentuk kegiatan tersebut umumnya adalah pelatihan, sosialisasi peraturan baru, pelantikan, dan sebagainya. Kegiatan-kegiatan tersebut perlu dicatat dan dikelola datanya sebagai dokumentasi atau rujukan dan pertimbangan dalam kegiatan berikutnya. Kegiatan ini memerlukan perencanaan mulai dari persiapan, pembuatan jadwal, penyebaran undangan via email, sampai kepada pelaksanaan dan pencatatan kehadiran peserta yang diundang. Studi kasus dilakukan di PT Pelni Indonesia sebagai perusahaan Pelayaran Nasional Indonesia yang sering melakukan kegiatan internal di dalam perusahaan. Permasalahan yang terjadi pada pengelolaan kegiatan perusahaan di PT Pelni adalah selama ini masih menggunakan sistem manual. Proses pendaftaran peserta, pendataan peserta, pengiriman undangan, pencatatan kehadiran peserta dan lain sebagainya dilakukan dengan tulisan tangan dan disimpan dalam bentuk file excel. Tentunya hal ini menyulitkan dalam pencarian dan pengelolaan data, serta memungkinkan terjadinya kehilangan data atau terselipnya dokumen. Salah satu solusi yang
\end{abstract}


dapat digunakan untuk mengatasi permasalahan tersebut adalah dengan membangun sistem informasi pengelolaan data kegiatan perusahaan. Sistem manajemen dapat membantu bagian HRD untuk pengelolaan data yang dibutuhkan dalam pelaksanaan kegiatan yang dilaksanakan oleh perusahaan. Teknologi QR Code juga digunakan untuk enkripsi nomor undangan peserta, verifikasi data peserta dan untuk mencatat kehadiran. Hasil dari pengembangan sistem ini adalah sebuah sistem pengelolaan data kegiatan perusahaan dengan memanfaatkan teknologi Quick Response Code (QR Code). QR Code yang dihasilkan dapat menyimpan berbagai data peserta hanya dalam 1 kode saja dan digunakan untuk verifikasi data peserta.

Kata Kunci : Undangan kegiatan; Validasi qr code; Quick response code

\section{Pendahuluan}

Kegiatan dalam suatu perusahaan atau institusi merupakan sesuatu hal yang biasa dilakukan, bentuk-bentuk kegiatan tersebut umumnya adalah pelatihan, sosialisasi peraturan baru, pelantikan, dan sebagainya. Kegiatan ini biasanya dikelola oleh Departemen HRD (Human Resource Department) yang bertanggung jawab terhadap data sumber daya manusia yang ada di dalam perusahaan. Kegiatan yang ada pada perusahaan biasanya meliputi pelatihan, sosialisasi peraturan baru, pelantikan, dan sebagainya. Banyaknya kegiatan yang diakukan perusahaan memerlukan pengelolaan data kegiatan dengan baik dan benar, sehingga memerlukan suatu sistem informasi pengelolaan data kegiatan yang dapat membantu bagian HRD dalam pelaksanaan kegiatan tersebut. Selama ini proses persiapan dan pelaksanaan studi ekskursi dilakukan secara manual oleh staff HRD bagian sumber daya manusia, mulai dari peremajaan pegawai sebagai peserta, pembuatan jadwal kegiatan, sosialisasi, pengarsipan dan pelaksanaan kegiatan. Permasalahan lainnya adalah banyaknya tumpukan kertas dokumen yang tidak tersimpan dengan baik, menyebabkan data yang dimiliki sulit ditelusuri dan dikelola.

Oleh karena itu salah satu solusi yang dapat diterapkan adalah dengan mengembangkan sistem informasi pengelolaan data kegiatan perusanaan dengan menerapkan teknologi QR Code. Sistem pengelolaan data kegiatan perusahaan ini dikembangkan berbasis web, sehingga aplikasi ini dapat diakses dari berbagai perangkat baik itu komputer maupun telepon pintar (smartphone) menggunakan browser yang ada. Untuk menyimpan datanya sistem ini menggunakan database Mysql. Sistem informasi pengelolaan data kegiatan ini diharapkan dapat membantu departemen HRD untuk pengelolaan data yang dibutuhkan dalam pelaksanaan kegiatan perusahaan. QR Code digunakan untuk enkripsi data peserta dan dapat digunakan untuk mencatat kehadiran dan verifikasi data peserta. Sistem informasi ini diharapkan dapat memudahkan perusahaan dalam penyampaian informasi kepada peserta dan teknologi QR Code dapat membantu proses pendataan peserta. Berdasarkan uraian latar belakang tersebut, maka perlu dilakukan penelitian mendalam untuk mengembangkan sistem informasi pengelolaan data kegiatan perusahaan yang semakin banyak kegiatannya dengan menerapkan teknologi QR Code. Sistem informasi pengelolaan data kegiatan perusahaan yang dihasilkan diharapkan dapat mempermudah dan mempercepat proses pengolahan data 
kegiatan perusahaan, sehingga segala sesuatu tentang data kegiatan perusahaan dapat diperoleh dengan waktu yang singkat.

QR (Quick Respone) Code adalah bentuk evolusi kode batang dari satu dimensi menjadi dua dimensi (Yohana, 2017). QR Code dikembangkan oleh Denso Wave, Denso Wave merupakan divisi Denso Corporation yang merupakan sebuah perusahaan di Jepang dan dipublikasikan pada tahun 1994. QR Code sudah mendapatkan standarisasi internasional dan standarisasi dari Jepang berupa ISO/IEC18004 dan JIS-X-0510. QR Code bertujuan untuk memberikan respon dan informasi cepat kepada pengguna, QR Code berbeda dengan barcode. Barcode menyimpan informasi secara horizontal, sedangkan QR Code menyimpan informasi secara horizontal dan vertikal. Hal ini membuat QR Code dapat menyimpan informasi lebih banyak dibandingkan dengan Barcode yang hanya menyimpan informasi secara horizontal, (Adi Musthofa. Novan, 2016) QR Code memiliki ukuran yang relatif lebih kecil dibandingkan dengan barcode, selain itu QR Code juga tahan terhadap kerusakan hal ini disebabkan QR Code mampu memperbaiki kesalahan sampai dengan 30\% tergantung dengan ukuran dan versi QR Code tersebut. Versi simbol QR Code antara versi 1 sampai dengan versi 40, semakin banyak jumlah data yang disimpan maka simbol QR Code akan semakin besar. Setiap versi QR Code memiliki kapasitas data yang sesuai dengan jumlah data, jenis karakter, dan tingkat kesalahan koreksi (Yohana, 2017).

Saat ini penggunaan $Q R$ Code sudah cukup luas. Banyak negara di dunia, terutama Jepang, telah menerapkan teknologi $Q R$ Code pada perindustriannya. Sementara di Indonesia, $Q R$ Code sudah diterapkan pada beberapa perusahaan. Salah satunya adalah pada surat kabar Kompas, yang mengklaim sebagai pelopor penggunaan $Q R$ Code di Indonesia, yang diterbitkan oleh Kelompok Kompas Gramedia (Mihardja, 2009). Hal ini terlihat pada surat kabar tersebut dimana terdapat $Q R$ Code yang merepresentasikan artikel pada surat kabar tersebut. Namun hingga pada saat ini, $Q R$ Code baru digunakan terbatas untuk menyimpan data teks seperti alamat URL, nomor telepon, informasi, dan lain-lain. Belum ada aplikasi maupun penelitian untuk menyimpan bentuk data lain pada $Q R$ Code. Padahal $Q R$ Code banyak digunakan untuk keperluan komersil seperti iklan, sedangkan iklan yang ditambahkan data lain selain teks, misalnya gambar, akan menambah daya tarik konsumen.

$Q R$ Code adalah image berupa matriks dua dimensi yang memiliki kemampuan untuk enyimpan data di dalamnya. $Q R$ Code merupakan evolusi dari kode batang (barcode). Barcode merupakan sebuah simbol penandaan objek nyata yang terbuat dari pola batang-batang berwarna hitam dan putih agar mudah untuk dikenali oleh komputer. Contoh sebuah $Q R$ Code dapat dilihat pada gambar 1 .

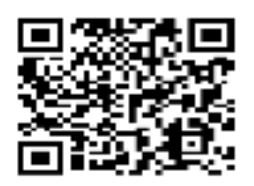

Sumber : (M.P. Nugraha, 2011)

Gambar 1. Contoh $Q R$ Code 
Oleh karena itu, dari latar belakang di atas, perlu dilakukan studi dan analisis mengenai kemungkinan pembangkitan $Q R$ Code dari data berbentuk gambar. Studi tersebut diimplementasikan menjadi sebuah perangkat lunak $Q R$ Code generator dan $Q R$ Code reader untuk kemudian dilakukan pengujian terhadap perangkat lunak tersebut. Dari pengujian yang dilakukan dapat diketahui kelayakan data gambar disimpan dalam $Q R$ Code.

\section{Metode Penelitian}

Pada bagian ini akan dijelaskan mengenai metodologi penelitian, yaitu metode pengembangan sistem dan perancangan sistem.

\subsection{Metode pengembangan sistem}

Metode penelitian yang digunakan untuk pengembangan sistem pengelolaan kegiatan perusahaan menggunakan identifikasi qr code adalah metode propotype. Metode pengembangan sistem prototyping adalah salah satu metode siklus hidup sistem yang didasarkan pada konsep model bekerja (working model). Tujuannya adalah mengembangkan model menjadi sistem final. Ciri dari metode ini adalah pengembang dan pelanggan dapat melihat dan melakukan pengerjaan dengan bagian dari sistem komputer dari sejak awal proses pengembangan.

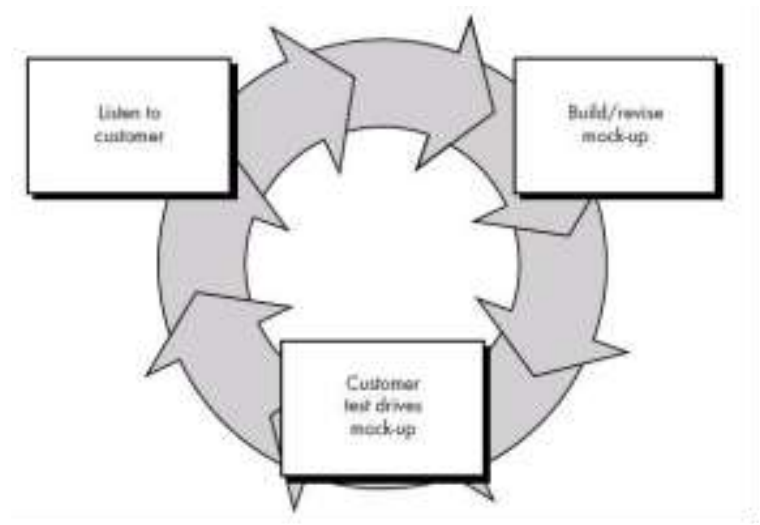

Sumber : (Pressman, 2005)

Gambar 2. Metode pengembangan sistem prototype

\subsection{Perancangan Sistem}

Pada bagian ini akan dijelaskan mengenai perancangan sistem yang terdapat pada aplikasi pengelolaan kegiatan perusahaan menggunakan validasi QR Code untuk mencatat kehadiran peserta. Perancangan sistem mulanya diawali dengan menentukan segala keperluan yang akan memenuhi apa yang dibutuhkan oleh sistem, siapa yang mengambil langkah dan bagaimana cara menyesuaikannya. Pada dasarnya perancangan sistem bergerak dari input menuju ke output sistem, yang terdiri dari reports dan file untuk memenuhi kebutuhan organisasi (Al Fatta, 2015). 


\section{Hasil dan Pembahasan}

\subsection{Unified Modeling Language (UML)}

UML (Unified Modeling Language) adalah salah satu standar bahasa yang banyak digunakan di dunia industri untuk mendefinisikan kebutuhan, membuat analisis dan desain alur suatu sistem, serta dapat menggambarkan arsitektur dalam suatu pemrograman yang berorientasi objek (Rosa, 2014).

Menurut (Gata, 2013), Unified Modeling Language (UML) adalah bahasa spesifikasi standar yang dipergunakan untuk mendokumentasikan, menspesifikasikan dan membangun perangkat lunak. UML merupakan metodologi dalam mengembangkan sistem berorientasi objek dan juga merupakan alat untuk mendukung pengembangan sistem. Alat bantu yang digunakan dalam perancangan berorientasi objek berbasiskan UML adalah sebagai berikut :

a. Use Case Diagram

Use case diagram merupakan pemodelan untuk kelakuan (behavior) sistem informasi yang akan dibuat. Use case digunakan untuk mengetahui fungsi apa saja yang ada di dalam sistem informasi dan siapa saja yang berhak menggunakan fungsi-fungsi tersebut.

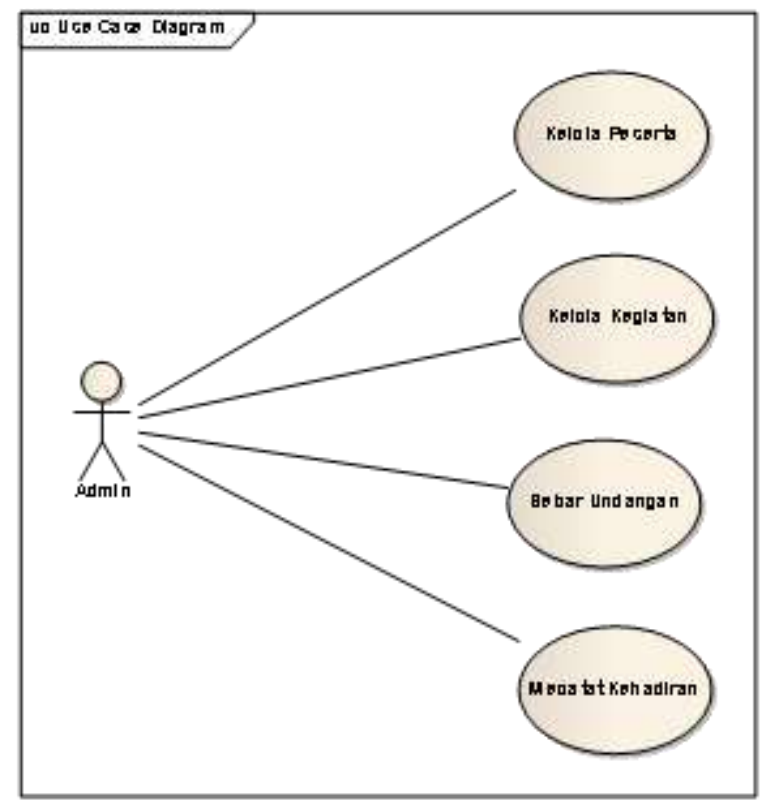

Sumber : Hasil Penelitian (2021)

Gambar 3. Use case diagram

b. Diagram Aktivitas (Activity Diagram)

Activity Diagram menggambarkan workflow (aliran kerja) atau aktivitas dari sebuah sistem atau proses bisnis. 


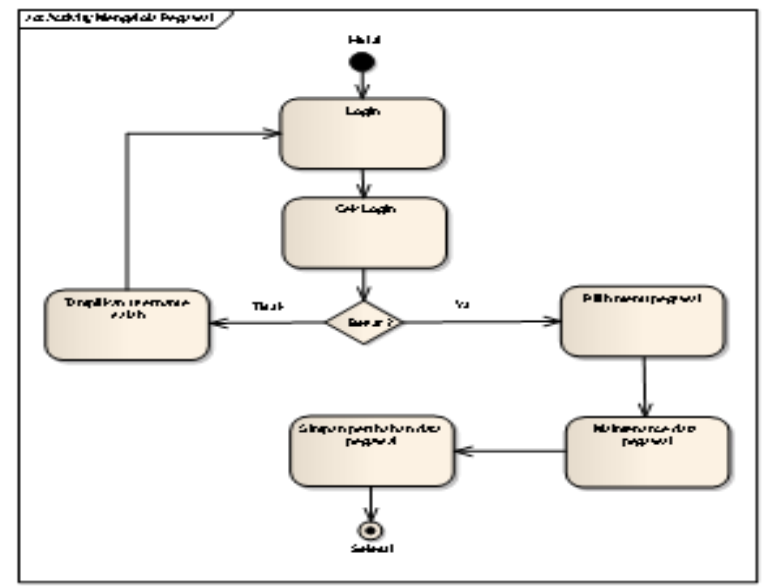

Sumber : Hasil Penelitian (2021)

Gambar 4. Activity diagram kelola pegawai

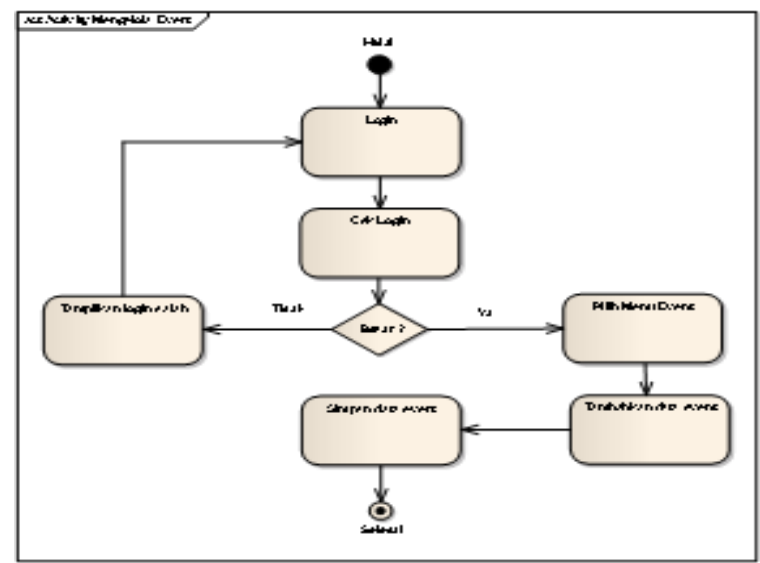

Sumber : Hasil Penelitian (2021)

Gambar 5. Activity diagram kelola kegiatan

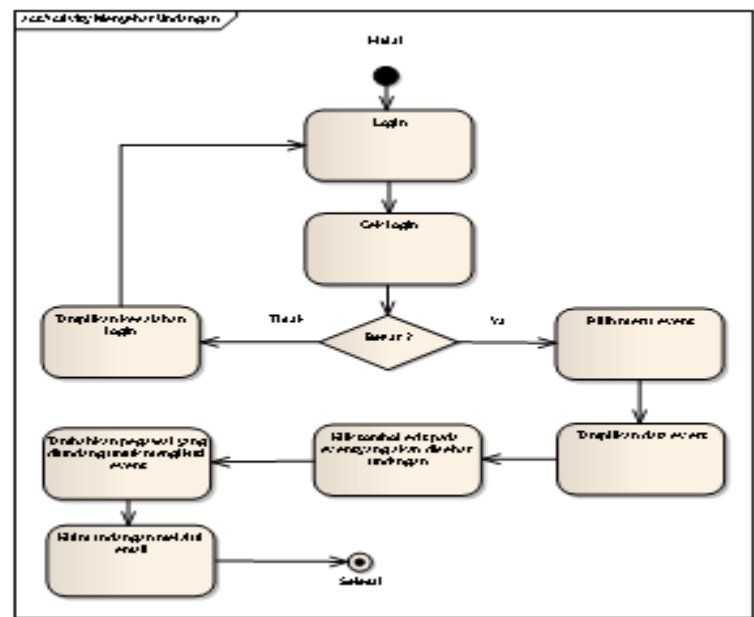

Sumber : Hasil Penelitian (2021)

Gambar 6. Activity diagram sebar undangan 


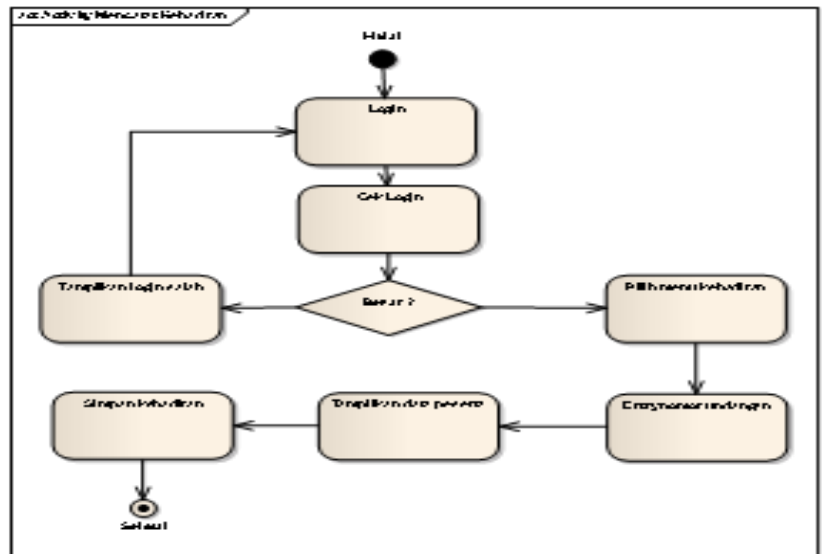

Sumber : Hasil Penelitian (2021)

Gambar 7. Activity diagram mencatat kehadiran

c. Diagram Urutan (Sequence Diagram)

Sequence Diagram menggambarkan kelakuan objek pada use case dengan mendeskripsikan waktu hidup objek dan pesan yang dikirimkan dan diterima antar objek.

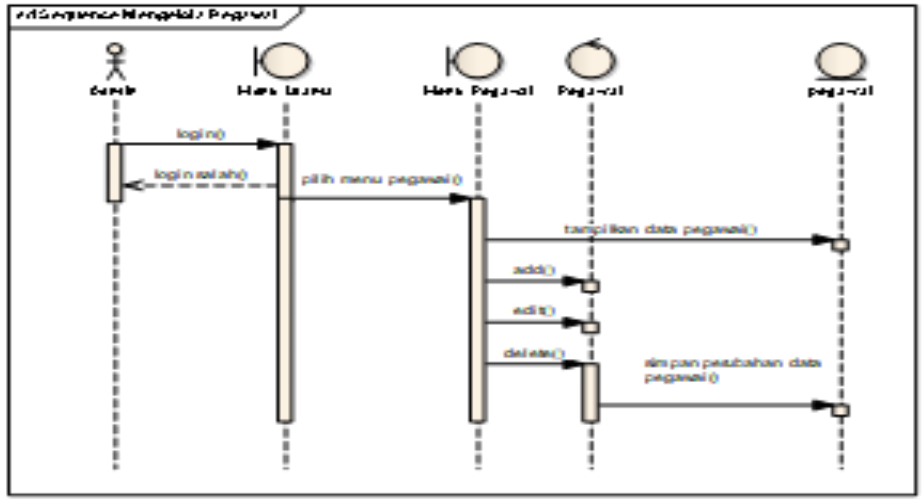

Sumber : Hasil Penelitian (2021)

Gambar 8. Sequence diagram kelola pegawai

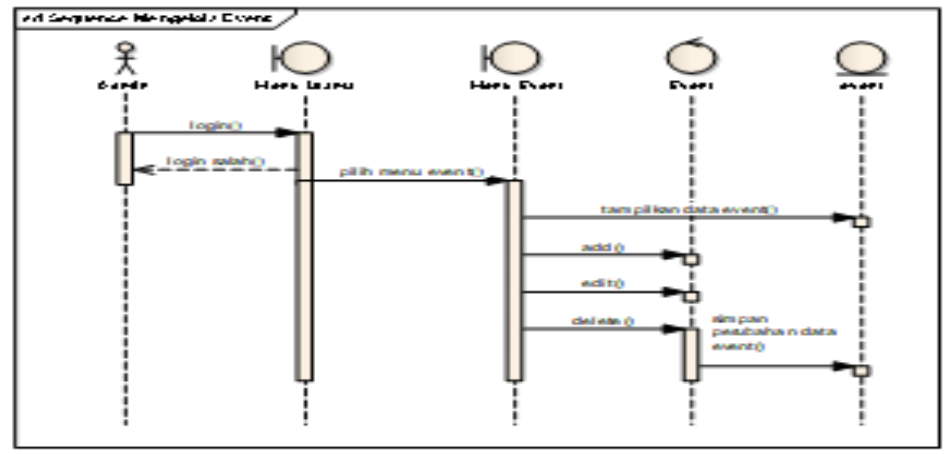

Sumber : Hasil Penelitian (2021)

Gambar 9. Sequence diagram kelola kegiatan 


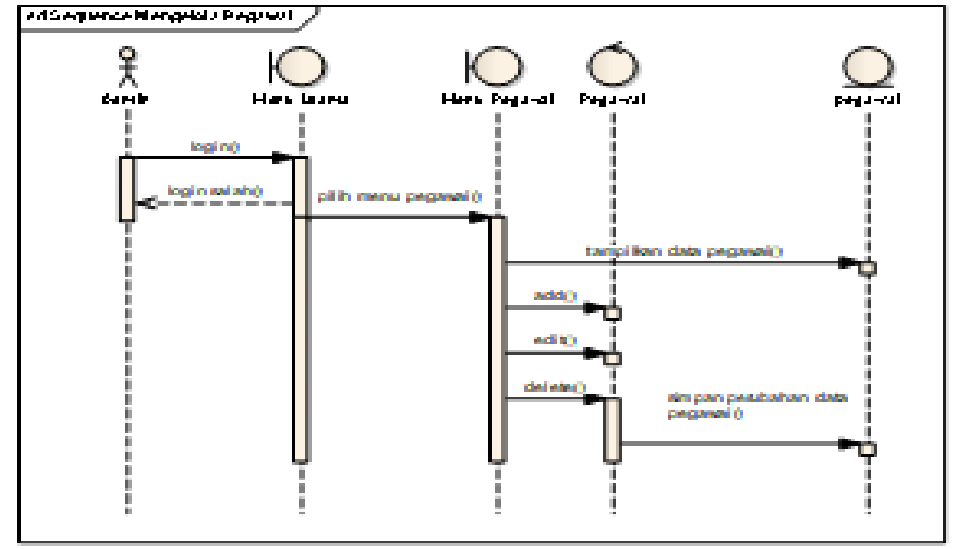

Sumber : Hasil Penelitian (2021)

Gambar 10. Sequence diagram sebar undangan

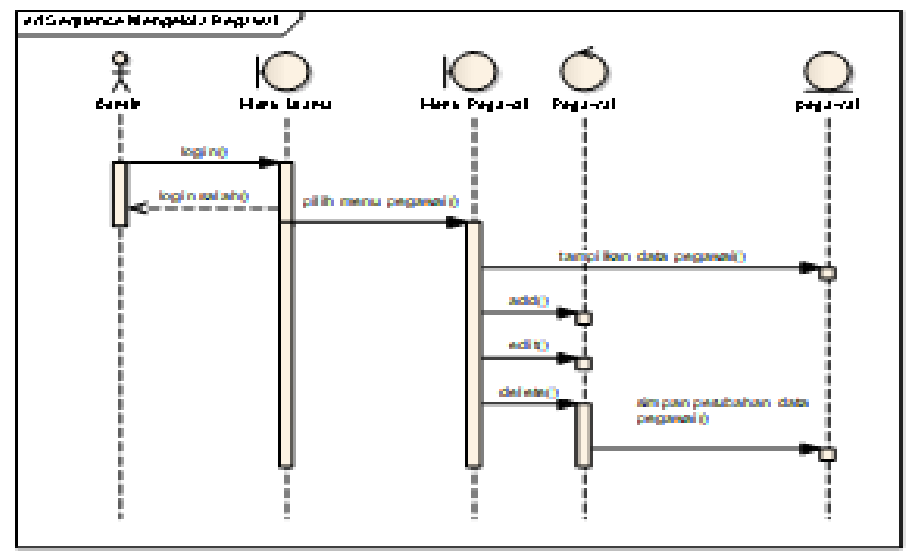

Sumber : Hasil Penelitian (2021)

Gambar 11. Sequence diagram mencatat kehadiran

\subsection{Rancangan database}

Menurut (Connolly, 2002), database is a single, large repository of data which can be used simultaneously by many departements and users atau dengan kata lain basis data merupakan tempat penyimpanan data yang besar dan tunggal yang dapat digunakan secara bersamaan oleh beberapa departemen atan pengguna. Menurut (Connolly, 2002) metodologi perancangan adalah pendekatan terstruktur yang menggunakan bantuan prosedur, teknik, peralatan, dan dokumentasi untuk mendukung dan memfasilitasi proses perancangan. Tujuannya membimbing perancang menggunakan teknik dengan benar pada setiap tahap proyek. Dan juga membantu perancang untuk merencanakan, mengatur, mengendalikan, dan mengevaluasikan proyek pengembangan basis data.

Menurut (Whitehorn, 2003) normalisasi merupakan suatu proses yang memudahkan desain struktur tabel secara benar sehingga query yang tak dapat ditanyakan tidak muncul. Disamping itu, normalisasi cenderung meminimumkan duplikasi data di dalam suatu basis data. 
Ini memiliki keunggulan dalam mengurangi ruang simpan yang dibutuhkan maupun mempercepat query.

Berikut adalah rancangan database yang digunakan pada sistem pengelolaan data kegiatan perusahaan.

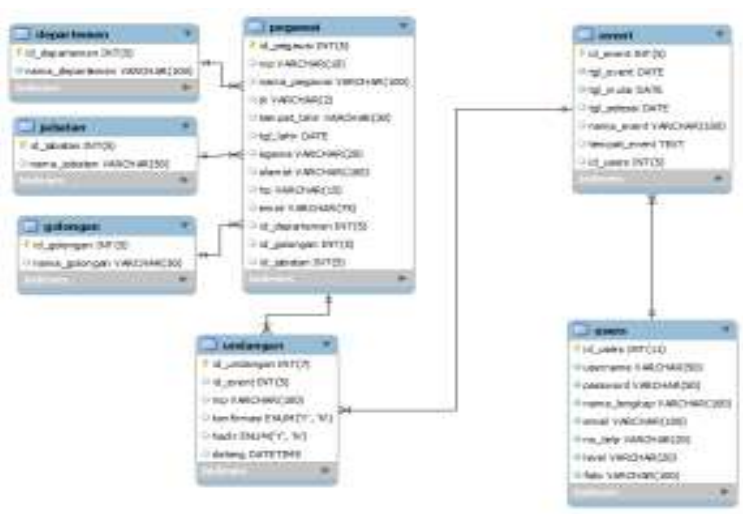

Sumber : Hasil Penelitian (2021)

Gambar 12. Rancangan database

\subsection{Tampilan Menu}

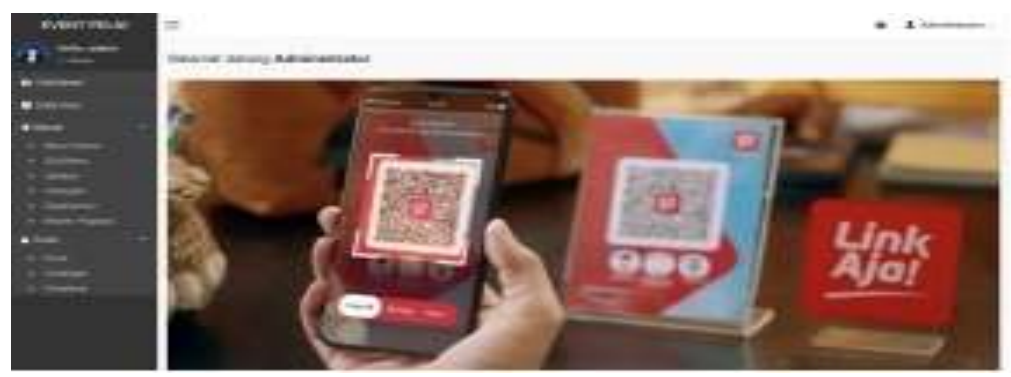

Sumber : Hasil Penelitian (2021)

Gambar 13. Halaman utama

Halaman utama berisi menu-menu di sebelah kanan yang dapat diakses setelah user berhasil login. Pada halaman ini user dapat mengases menu sesuai dengan hak aseksnya masing-masing. Berikut adalah tampilan halaman utama.

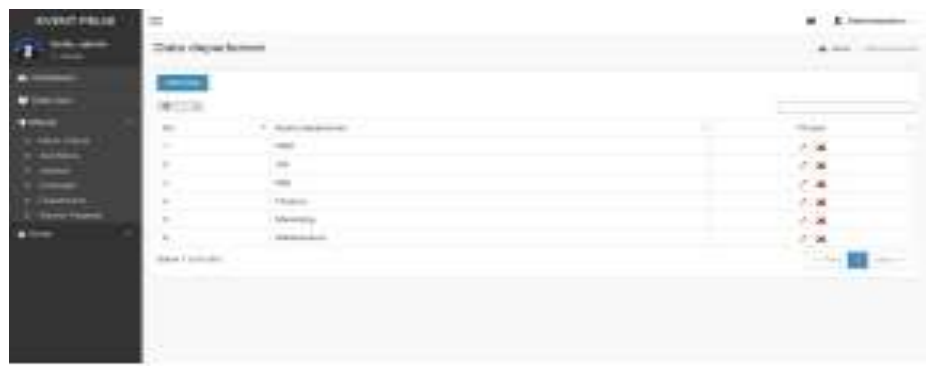

Sumber : Hasil Penelitian (2021)

Gambar 14. Modul departemen 
Modul departemen seperti telihat pada gambar di bawah. Admin dapat melakukan menambah, merubah dan menghapus data departemen.

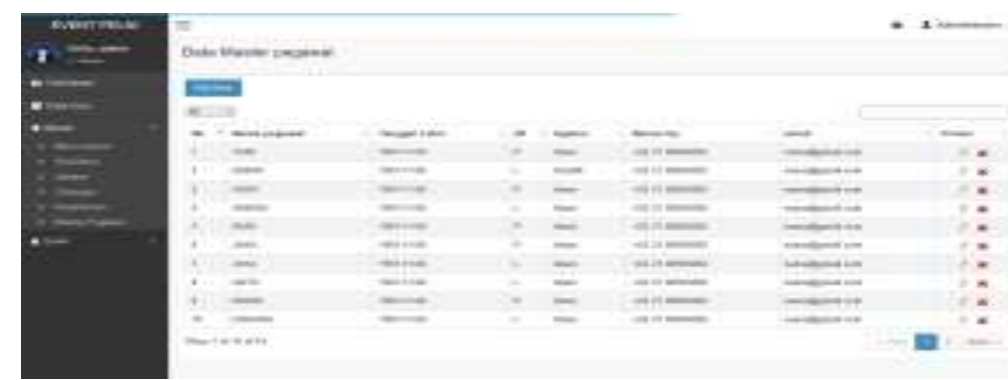

Sumber : Hasil Penelitian (2021)

Gambar 15. Modul pegawai

Berikut adalah implementasi pada modul pegawai seperti telihat pada gambar di bawah. Admin dapat melakukan menambah, merubah dan menghapus data pegawai. Peserta yang mengikuti kegiatan di perusahaan adalah para pegawai.

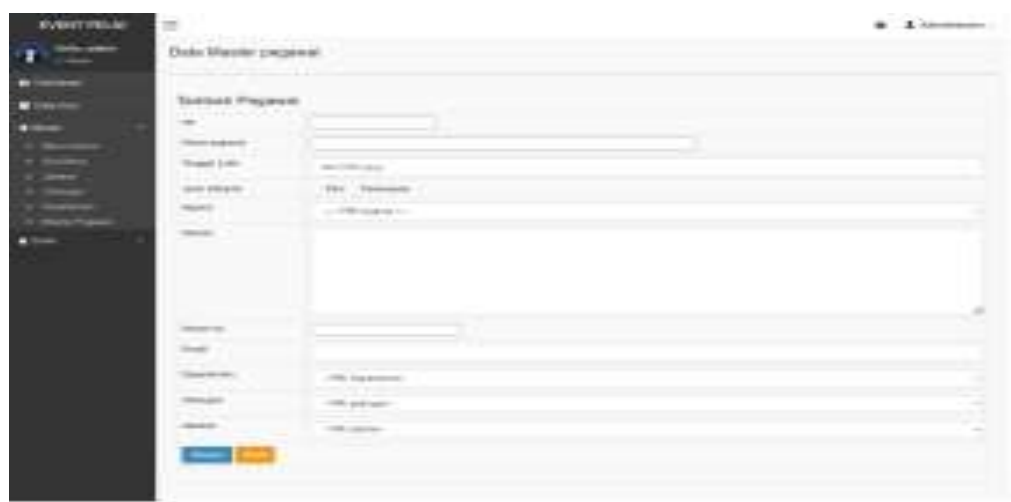

Sumber : Hasil Penelitian (2021)

Gambar 16. Form tambah pegawai

Untuk form tambah data pegawai adalah seperti telihat pada gambar di bawah. Hanya admin yang dapat melakukan penambahan pegawai.

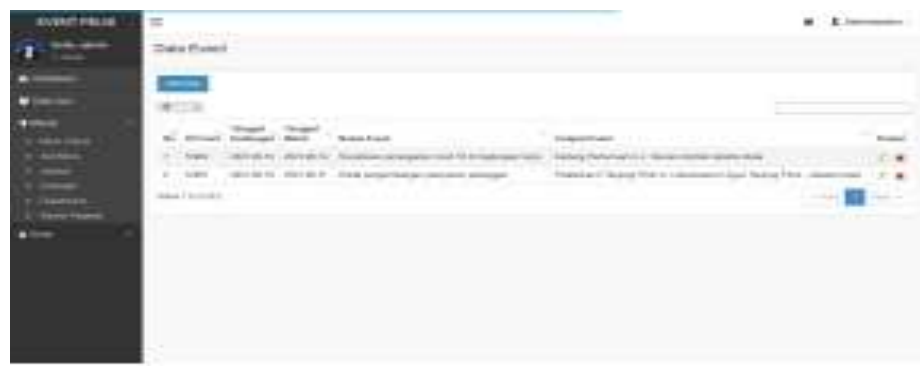

Sumber : Hasil Penelitian (2021)

Gambar 17. Modul kegiatan

Modul kegiatan seperti telihat pada gambar di bawah. Admin dapat melakukan menambah, merubah dan menghapus data kegiatan. 


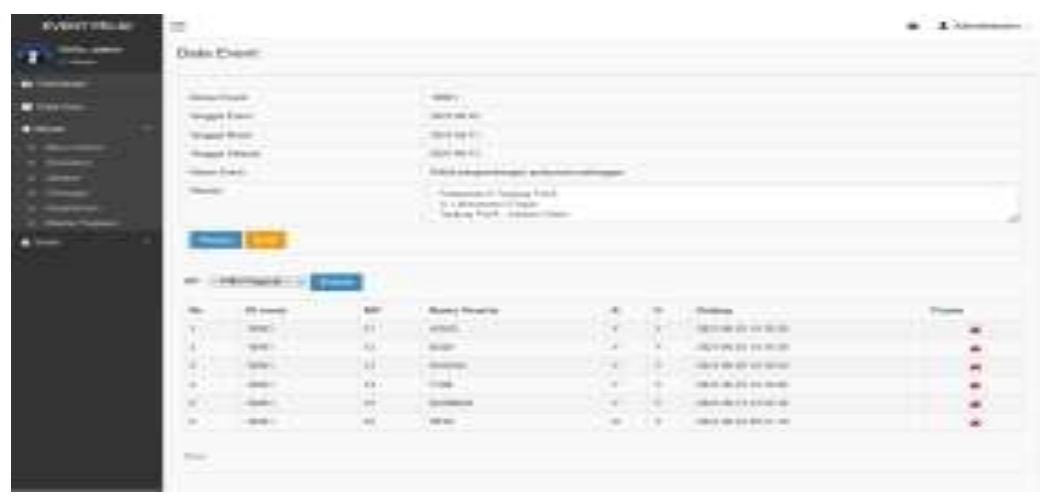

Sumber : Hasil Penelitian (2021)

Gambar 18. Halaman tambah peserta kegiatan

Form untuk menambah peserta yang akan mengikuti kegiatan perusahaan,.

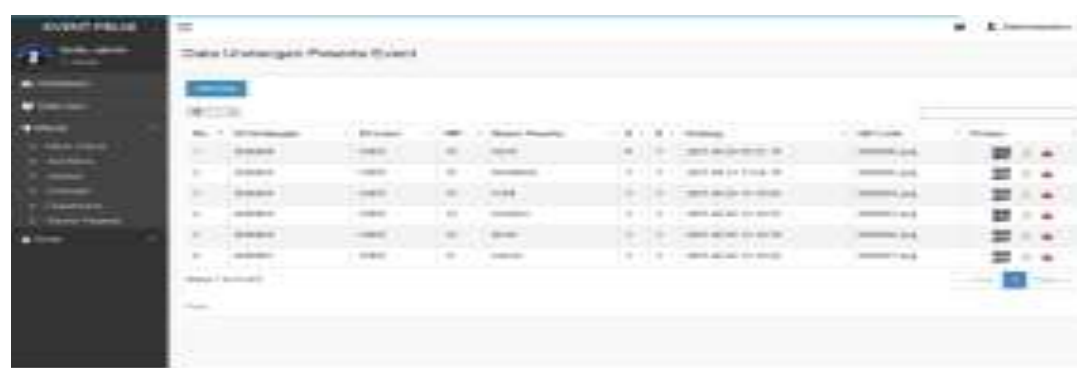

Sumber : Hasil Penelitian (2021)

Gambar 19. Modul undangan

Pada halaman ini admin dapat membuat qr code dengan cara menekan mengklik icon QR-Code dan sistem langsung mengirim undangan kegiatan melalui email peserta yang telah terdaftar di data master pegawai, di mana admin dapat menambah, merubah, menghapus dan membuat QR Code yang berisi kode nomor undangan.

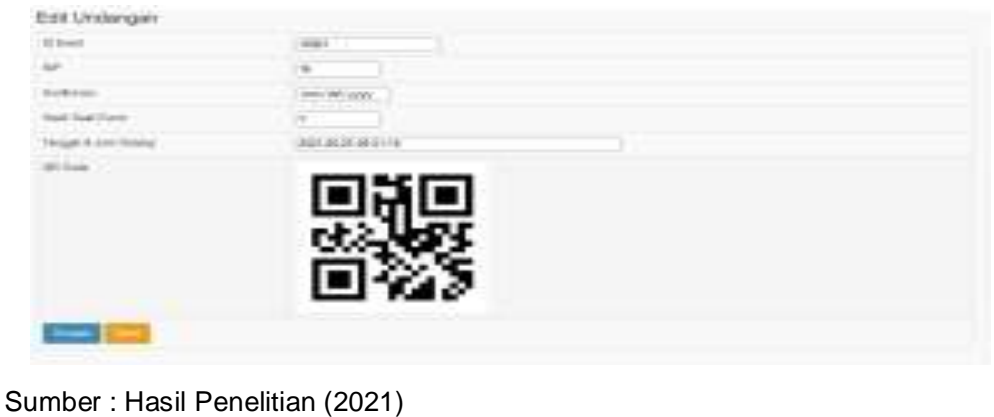

Gambar 20. Qr Code Undangan

Pada bagian edit undangan ini admin dapat melihat qr code yang telah dibuat pada saat admin menekan icon qr-code. 


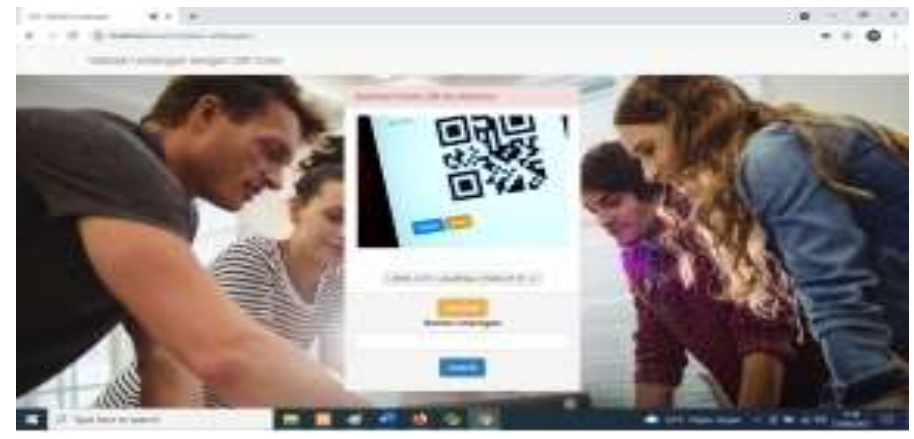

Sumber : Hasil Penelitian (2021)

Gambar 21. Validasi undangan

Pada bagian ini admin dapat mengecek kehadiran peserta melalui nomor undangan yang tersimpan dalam bentuk QR Code menggunakan webcam laptop, atau memasukkan nomor undangan. Berikut adalah tampilan halaman validasi undangan.

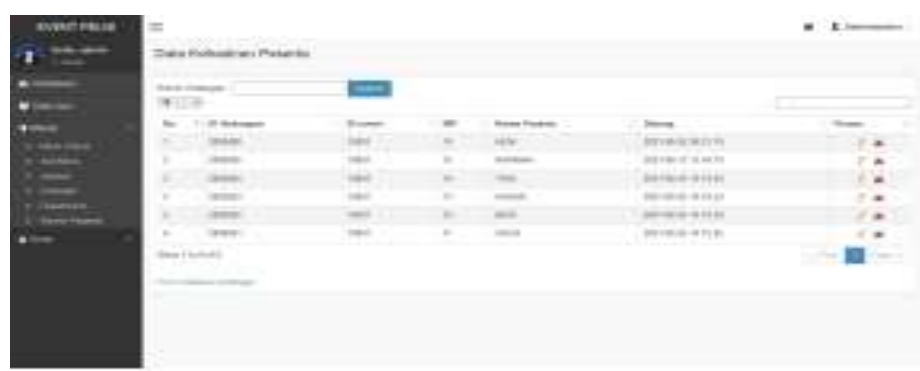

Sumber : Hasil Penelitian (2021)

Gambar 22. Data kehadiran peserta

Setelah kode undangan divalidasi dan kodenya benar, maka sistem akan menampilkan data kehadiran peserta.

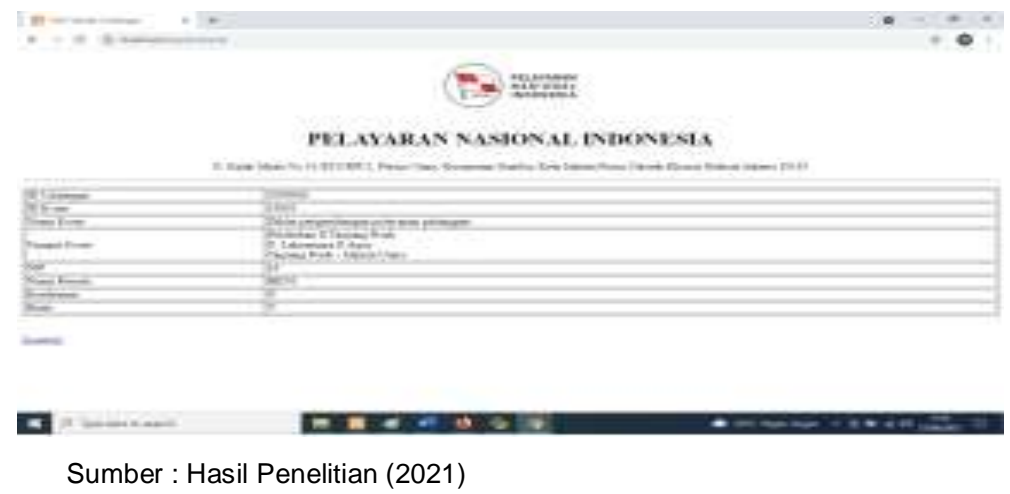

Gambar 23. Cetak Kehadiran

Pada halaman ini admin dapat melihat apabila kode undangan berisi QR Code yang ditangkap oleh webcam berhasil dikenal.. 


\section{Kesimpulan}

Kegiatan dalam suatu perusahaan atau institusi merupakan sesuatu hal yang biasa dilakukan, bentuk-bentuk kegiatan tersebut umumnya adalah pelatihan, sosialisasi peraturan baru, pelantikan, dan sebagainya. Kegiatan-kegiatan tersebut perlu dicatat dan dikelola datanya sebagai dokumentasi atau rujukan dan pertimbangan dalam kegiatan berikutnya. Kegiatan ini memerlukan perencanaan mulai dari persiapan, pembuatan jadwal, penyebaran undangan via email, sampai kepada pelaksanaan dan pencatatan kehadiran peserta yang diundang. Studi kasus dilakukan di PT Pelni Indonesia sebagai perusahaan Pelayaran Nasional Indonesia yang sering melakukan kegiatan internal di dalam perusahaan. Sistem manajemen dapat membantu bagian HRD untuk pengelolaan data yang dibutuhkan dalam pelaksanaan kegiatan yang dilaksanakan oleh perusahaan. Teknologi QR Code juga digunakan untuk enkripsi nomor undangan peserta, verifikasi data peserta dan untuk mencatat kehadiran. Hasil dari pengembangan sistem ini adalah sebuah sistem pengelolaan data kegiatan perusahaan dengan memanfaatkan teknologi Quick Response Code (QR Code). QR Code yang dihasilkan dapat menyimpan berbagai data peserta hanya dalam 1 kode saja dan digunakan untuk verifikasi data peserta.

\section{Daftar Pustaka}

Adi Musthofa. Novan, M. S. (2016). IMPLEMENTASI QUICK RESPONSE (QR) CODE PADA APLIKASI VALIDASI DOKUMEN MENGGUNAKAN PERANCANGAN UNIFIED MODELLING LANGUAGE (UML). Jurnal Antivirus, $10 \quad$ (1), $42-50$. doi:https://doi.org/10.35457/antivirus.v10i1.87

Al Fatta, H. M. (2015). ANALISIS PENGEMBANGAN DAN PERANCANGAN SISTEM INFORMASI AKADEMIK SMART BERBASIS CLOUD COMPUTING PADA SEKOLAH MENENGAH UMUM NEGERI (SMUN) DI DAERAH ISTIMEWA YOGYAKARTA. Jurnal Telematika, 8 (2). doi:http://dx.doi.org/10.35671/telematika.v8i2.396

Connolly, T. M. (2002). Database Systems. USA: Addison Wesley.

Gata, W. G. (2013). Sukses Membangun Aplikasi Penjualan dengan Java. Jakarta: ELex Media Komputindo.

M.P. Nugraha, R. M. (2011). Pengembangan Aplikasi QR Code Generator dan QR Code Reader dari Data Berbentuk Image. Konferensi Nasional Informatika, (pp. 148-149). Bandung.

Mihardja, T. (2009, 6 15). QR Code Kompas Perkaya Konten bagi Pembaca. (kompas.com, $\begin{array}{lllll}\text { Ed.) } & \text { Retrieved } & 7 & 7, & \text { from }\end{array}$ https://tekno.kompas.com/read/2009/06/15/0850503/QR.Cod

Pressman, S. R. (2005). E-book Software Engineering: a Practitioner's Approach. 
Rosa, A. S. (2014). Rekayasa Perangkat Lunak Terstruktur dan Berorientasi Objek. Bandung: Informatika.

Whitehorn, M. D. (2003). Seluk Beluk Database Relasional. Jakarta: Erlangga.

Yohana, T. W. (2017). APLIKASI TEKNOLOGI QR ( QUICK RESPONSE ) CODE IMPLEMENTASI YANG UNIVERSAL. Jurnal KOMPUTAKI, 3 (1), 66-82. Retrieved from https://www.unaki.ac.id/ejournal/index.php/komputaki/article/view/154 